Kredo 4 (2021)
KREDO: Jurnal Ilmiah Bahasa dan Sastra
Terakreditasi Sinta 4 berdasarkan Keputusan
Direktorat Jenderal Penguatan Riset dan
Pengembangan, Kementerian Riset, Teknologi dan
Pendidikan Tinggi Republik Indonesia
Nomor: 23/E/KPT/2019.08 Agustus 2019
https://jurnal.umk.ac.id/index.php/kredo/index

\title{
TELAAH TINDAK TUTUR ILOKUSI GURU DALAM INTERAKSI PEMBELAJARAN BAHASA INDONESIA
}

\author{
Akram Budiman Yusuf ${ }^{1}$, Abdul Karim², Sri Devi S. ${ }^{3}$ \\ akrambudimanyusuf@unismuh.ac.id \\ Universitas Muhammadiyah Makassar, Indonesia
}

Info Artikel
Sejarah Artikel
Diterima
22 Februari 2021
Disetujui
8 April 2021
Dipublikasikan
9 April 2021
Keywords
illocution
Indonesian language
learning

Kata Kunci

ilokusi

pembelajaran bahasa

Indonesia
Abstract

This study aims to (1) describe a form of illocutionary acts in learning Indonesian teacher at SMP Negeri 1 Makassar, and (2) describes the functions of illocutionary acts in learning Indonesian teacher at SMP Negeri 1 Makassar. This study was a qualitative research with descriptive design. Unit analysis data used in the form of tangible teacher speech illocutionary acts in Indonesian language learning in SMP Negeri 1 Makassar. The research data used in the form of human instruments, the researchers themselves with the tools of data collection guidelines. Analysis of the data in this study includes data collection, data reduction, data presentation, and conclusion / verification. Based on the findings of the research that has been done it is found in the form of a form, and function. First, a form of illocutionary acts in learning Indonesian teacher at SMP Negeri 1 Makassar there are three; (1) the imperative sentence, which consists of (a) the imperative sentence request, (b) the imperative sentence licensing, (c) the imperative sentence solicitation, (d) the : imperative sentence errands, and (e) the imperative sentence ban, (2) sentences interrogative, which consists of (a) the total interrogative sentence, and (b) a partial interrogative sentence, (3) declarative sentences consisting of (a) an active declarative sentences, and (b) passive declarative sentences. Second, the function of illocutionary acts in learning Indonesian teacher in junior high school 1 Makassar there are three; (1) function assertive, comprising (a) states, (b) propose, (c) brag, (d) to complain, (e) report, $(f)$ approve, and $(g)$ protested, (2) function directive, that consist of

: (a) the request, (b) a prohibition, (c) licensing, (d) the follow question, (e) follow orders and $(f)$ acts of counsel, and (3) the function expressive consisting of (a) regards, (b) grateful, (d) apologized, and (e) a compliment.

\section{Abstrak}

Penelitian ini bertujuan untuk (1) mendeskripsikan bentuk ilokusi guru saat proses pengajaran bahasa Indonesia di SMPN 1 Makassar, dan (2) memaparkan manfaat ilokusi guru saat pengajaran bahasa Indonesia di SMPN 1 Makassar. Jenis penelitian ini adalah kualitatif dengan rancangan deskriptif. Unit analisis dalam penelitian ini adalah ilokusi wicara pendidik dalam pembelajaran bahasa Indonesia di SMP Negeri 1 Makassar. Data penelitian yang digunakan berupa instrumen manusia, peneliti sendiri dengan alat pedoman pengumpulan data. Analisis data dalam penelitian ini meliputi pengumpulan data, reduksi data, penyajian data, dan penarikan kesimpulan / verifikasi. Berdasarkan temuan penelitian yang telah dilakukan ditemukan dalam bentuk bentuk dan fungsi. Pertama, bentuk ilokusi dalam pembelajaran guru bahasa Indonesia di SMP Negeri 1 Makassar ada tiga; (1) kalimat imperatif, yang terdiri dari (a) permintaan kalimat imperatif, (b) perizinan kalimat imperatif, (c) kalimat imperatif ajakan, (d) kalimat imperatif errands, dan (e) larangan kalimat imperatif, (2) kalimat interogatif, yang terdiri dari (a) total kalimat interogatif, dan (b) kalimat interogatif parsial, (3) kalimat deklaratif yang terdiri dari (a) kalimat deklaratif aktif, dan (b) kalimat deklaratif pasif. Kedua, fungsi ilokusi guru dalam pembelajaran bahasa Indonesia di SMP Negeri 1 Makassar ada tiga; (1) fungsi tegas, terdiri dari (a) menyatakan, (b) mengusulkan, (c) membual, (d) mengeluh, (e) melaporkan, (f) menyetujui, dan (g) memprotes, (2) arahan fungsi, yang terdiri dari (a) permintaan, (b) larangan, (c) perizinan, (d) pertanyaan berikut, (e) mengikuti perintah dan (f) tindakan nasihat, dan (3) fungsi ekspresif yang terdiri dari (a) salam, (b) terima kasih, (d) permintaan maaf, dan (e) pujian. 


Kredo 4 (2021)
KREDO: Jurnal Ilmiah Bahasa dan Sastra
Terakreditasi Sinta 4 berdasarkan Keputusan
Direktorat Jenderal Penguatan Riset dan
Pengembangan, Kementerian Riset, Teknologi dan
Pendidikan Tinggi Republik Indonesia
Nomor: 23/E/KPT/2019.08 Agustus 2019
https://jurnal.umk.ac.id/index.php/kredo/index

PENDAHULUAN

Bahasa merupakan sebuah alat komunikasi yang sangat efektif digunakan dalam kehidupan sosial manusia. Untuk melihat kedudukan bahasa sebagai alat interaksi maka bisa diketahui dengan cara melakukan sebuah pengamatan atau observasi yang relevan dengan berbagai kondisi dan situasi. Hilangnya sebuah eksitensi bahasa dalam dinamika interaksi dapat menimbulkan sebuah kesulitan antarpelaku komunikasi. Maka dari itu, peran dari sebuah bahasa sangatlah penting dalam dialektika komunikasi yang ada di tatanan masyarakat. Hal ini senada dengan pendapat Keraf (2009) yang mengatakan bahwa bahasa adalah sebuah alat yang digunakan untuk berkomunikasi antaranggota masyarakat yang berbentuk simbol bunyi yang dihasilkan oleh alat artikulasi manusia.

Beberapa rangkaian ujaran yang terbentuk dari konteks interaksi tidak lepas dari sebuah sistem yang mengatur tuturan untuk mencapai sebuah tujuan tertentu. Maka dari itu, senada dengan sistem bahasa yang diutarakan oleh Saussure dalam Ilham (2018) yang mengatakan bahwa sistem bahasa adalah sebuah kondisi yang harus selalu ada dalam pemakaian tanda secara nyata. Selanjutnya, ialah fungsi bahasa yang merupakan sebuah aspek penting dalam sebuah bahasa yang di mana menurut
Devianty (2017) yang memandang sebagai alat komunikasi, bahkan juga dapat di pandang menjadi fungsi utama dari bahasa tersebut.

Pokok acuan dalam dinamika fungsi bahasa mengacu pada makna atau maksud yang disematkan dalam suatu tuturan. Tanggapan terhadap tindakan yang dilakukan oleh penerima tuturan tidak lepas dari pembagian informasi yang telah dibagi berdasarkan tingkatannya. Dalam hal ini, bahasa bisa membantu manusia untuk saling berhubungan, belajar dan mengungkapkan semua yang ingin mereka katakan. Hubungan yang tercipta dari situasi tersebut pada hakikatnya akan menjadi sebuah kajian lisan yang dikenal sebagai istilah tindak tutur.

Tindak tutur merupakan aktivitas fungsional manusia dilihat dari eksitensi dirinya sebagai makhluk berbahasa. Maka dari itu sifat fungsional dapat memberikan sebuah pengaruh kepada manusia untuk lebih berusaha melakukan tindak tutur dengan baik sehingga dalam penyampaianya dapat tercapai dan dipahami oleh lawan tutur. Secara umum tindak tutur sendiri bisa ditemukan dalam kehidupan sehari-hari baik dalam ruang formal ataupun dalam konteks yang formal. Dalam hal ini, kontribusi tindak tutur sangat besar untuk menjaga kohesi komunikasi. Pandangan ini juga berlaku pada dunia pendidikan utamanya dalam proses 


Kredo 4 (2021)
KREDO: Jurnal Ilmiah Bahasa dan Sastra
Terakreditasi Sinta 4 berdasarkan Keputusan
Direktorat Jenderal Penguatan Riset dan
Pengembangan, Kementerian Riset, Teknologi dan
Pendidikan Tinggi Republik Indonesia
Nomor: 23/E/KPT/2019.08 Agustus 2019
https://jurnal.umk.ac.id/index.php/kredo/index

belajar mengajar antara pendidik dan peserta didik di ruang kelas.

Austin (1962) dalam (Ilham, 2018) membagi tuturan sebagai tindakan menjadi tiga macam yaitu tindak tutur lokusi, tindak tutur ilokusi, dan tindak tutur perlokusi. Yang dimana tindak tutur lokusi adalah sebuah tindak tutur yang mengungkapkan sesuatu. Dalam hal ini tindak tutur lokusi tidak memperhatikan sebuah maksud dan fungsi tuturan yang diungkapkan oleh penutur. Berikutnya, tindak tutur ilokusi yang merupakan sebuah tindak tutur yang berfungsi untuk memberikan infromasi terhadap lawan tutur, selain itu tindak tutur ilokusi juga dapat digunakan dalam melakukan sesuatu. Sedangkan tindak tutur perlokusi adalah sebuah tindak tutur yang dapat memperbesar pengaruh terhadap diri sang penutur.

Adapun tugas dari seorang pendidik dalam proses belajar mengajar yaitu dapat menciptakkan sebuah suasana belajar yang bisa memberikan dorongan atau motivasi terhadap peserta didik untuk bersungguh-sungguh dalam belajar. Maka dari itu guru dituntut untuk mempunyai keahlian dalam mengelolah pembelajaran dengan baik, seperti keahlian dalam mengelolah kelas, keahlian mengunakan berbagai macam metode belajar, dapat berinteraksi dengan baik dan bersikap dengan baik dalam kelas. Dalam proses belajar mengajar, terbentuk sebuah hubungan positif antara prilaku produktif peserta didik dan prilaku pendidik. Perilaku peserta didik sendiri terbentuk dari perilaku pendidiknya yang menunjukkan kehangatan, pengertian, persahabatan, serta mampu simpati terhadap perilaku anak.

Bahasa memegang peranan yang sangat penting dalam proses interaksi pembelajaran, sebab bahasa adalah salah satu alat atau media dalam proses interaksi pembelajaran. Dalam menyampaikan materi yang akan diajarkan alat atau sarana yang digunakan pendidik adalah bahasa. Peserta didik juga dapat mengerti penjelasan pendidik dengan mudah menggunakan bahasa.

Langkah yang dilakukan pendidik dalam memberikan ungkapan seperti meminta, menyuruh, memberikan perintah yang mengandung arti bukan saja dalam kata-kata semata. Misalnya, apabila seorang pendidik ingin meminta peserta didik untuk mengerjakan suatu hal, pendidik tidak sekadar meminta secara langsung, akan tetapi memulai dengan memakai stimulus, pertanyaan, atau ungkapan yang mengandung makna meminta. Oleh sebab itu, pendidik mempu meminta dan memberikan arahan kepada peserta didik secara verbal dan nonverbal memakai tindak tutur yang berlainan.

Berhubungan dengan keadaan di atas, penelitian yang dilakukan peneliti bertujuan untuk mengetahui macammacam tindak tutur yang dipakai oleh 


Kredo 4 (2021)
KREDO: Jurnal Ilmiah Bahasa dan Sastra
Terakreditasi Sinta 4 berdasarkan Keputusan
Direktorat Jenderal Penguatan Riset dan
Pengembangan, Kementerian Riset, Teknologi dan
Pendidikan Tinggi Republik Indonesia
Nomor: 23/E/KPT/2019.08 Agustus 2019
https://jurnal.umk.ac.id/index.php/kredo/index

pendidik dalam interaksi pengajaran bahasa Indonesia di Sekolah Menengah Pertama (SMP) Negeri 1 Makassar. Dasar yang dijadikan alasan oleh peneliti memilih SMPN 1 Makassar sebagai lokasi penelitian yaitu, belum pernah ada peneliti yang meneliti terkait tindak tutur yang dipakai dalam interaksi pengajaran bahasa Indonesia di SMPN 1 Makassar. Di samping itu, ditemukan fenomena kebahasaan dalam data awal yang menunjukkan keanekaragaman pemakaian bentuk tindakan yang diterapkan pendidik dalam interaksi pembelajaran di dalam kelas.

Melalui kajian ini, menghadirkan pengetahuan tentang ilmu bahasa yang dapat dinikmati kegunaannya tidak hanya dalam aspek bahasa saja namun, dapat dinikmati dalam berbagai aspek kegiatan manusia. Dalam pengajaran bahasa Indonesia, pemakaian tindak ilokusi pendidik adalah satu dari sekian contoh penelitian dari berbagai aspek kegiatan manusia yang mampu diteliti menggunakan kajian bahasa.

Penelitian ini relevan atau sejalan dengan salah satu penelitian tindak tutur yang diteliti oleh Asri (2017) dengan judul penelitian "Analisis Tindak Tutur Guru dan Siswa dalam Pembelajaran Bahasa Indonesia kelas XI MAN Bulukumba". Hasil penelitian menunjukkan bahwa terdapat berbagai jenis tindak tutur yang dipakai pendidik dan peserta didik dalam kelangsungan proses interaksi belajar mengajar.

405 | Jurnal Kredo

Vol. 4 No. 22021
Perbedaan penelitian Asri dengan penelitian ini terletak pada subjek penelitian dimana penelitian Asri meneliti tingkat Pendidikan Anak Sekolah Menengah Atas (SMA) dan subjek penelitian ini meneliti tingkat Pendidikan anak Sekolah Menengah Pertama (SMP). Selain subjek penelitian perbedaan yang lain yaitu, Penelitian asri meneliti tentang tuturan guru atau pendidik dan peserta didik dalam proses interaksi pengajaran bahasa Indonesia dan penelitian ini meneliti tentang tuturan pendidik dalam proses interaksi pengajaran bahasa Indonesia.

\section{KAJIAN TEORI}

\section{A. Hakikat Pragmatik}

Istilah pragmatik pertama kali digunakan oleh filsof kenamaan Moris (1938) (Yuniarti, 2016). Filsof ini memang mempunyai perhatian besar terhadap ilmu yang mempelajari sistem tanda (semiotik). Di dalam kajian semiotik, Charles Morris membedakan tiga konsep dasar, yaitu sintaksis, semantik dan pragmatik. Sintaksis mempelajari hubungan formal antara tanda-tanda, Semantik mempelajari hubungan antara tanda dengan objek, dan pragmatik mengakaji hubungan antara tanda dan penafsir. Tanda yang dimaksud di sini adalah tanda bahasa, bukan yang lain (Rahardi, 2005).

Berdasarkan teori yang telah dikemukakan, maka yang disebut 


Kredo 4 (2021)
KREDO: Jurnal Ilmiah Bahasa dan Sastra
Terakreditasi Sinta 4 berdasarkan Keputusan
Direktorat Jenderal Penguatan Riset dan
Pengembangan, Kementerian Riset, Teknologi dan
Pendidikan Tinggi Republik Indonesia
Nomor: 23/E/KPT/2019.08 Agustus 2019
https://jurnal.umk.ac.id/index.php/kredo/index

pragmatik adalah suatu kajian linguistik yang menelaah hubungan timbal balik antara fungsi dan bentuk tuturan. Dalam pragmatik pula, akan muncul terkait bagaimana jalan kejelasan makna penutur saat mengartikan kalimat dan mengkaji makna yang berkaitan dengan keadaan kalimat yang dilisankan.

Secara umum, Purwo (1990) mengemukakan empat bidang yang menjadi kajian dalam pragmatik, yaitu (1) deiksis, (2) praanggapan (presupposition), (3) tindak tutur (speec acts), dan impikatur percakapan (conversational implicature).

\section{B. Karakteristik Tindak Ilokusi Bahasa Indonesia}

Karakteristik tindak ilokusi bahasa Indonesia dalam interaksi antara penutur dan mitra tutur memiliki satuan pragmatis dan implikasi pragmatis. Satuan pragmatis dan implikasi pragmatis dibangun dari hasil percakapan antara penutur dan mitra tutur dengan memperhatikan suasana, waktu, tempat, dan tujuan tuturan. Dari percakapan itu akan muncul wujud, dan fungsi tindak ilokusi bahasa Indonesia.

\section{Wujud Tindak Ilokusi Bahasa}

\section{Indonesia}

Wujud verbal merupakan konstruksi kebahasaan dan bunyi tuturan yang secara produktif diujarkan dan didengar dalam bahasa lisan atau dituliskan dan dapat dibaca dalam bahasa tulis. Sesuai dengan tuturannya, wujud verbal dapat berupa morfem, kata, frasa, klausa, dan kalimat. Leech (2016) menjelaskan bahwa istilah deklaratif, interogatif, dan imperatif biasa digunakan secara khas dalam sintaksis. Sementara Rahardi (2005) membagi kalimat menurut maknanya yang meliputi (1) kalimat deklaratif, (2) kalimat interogatif, dan (3) kalimat imperatif. Kalimat-kalimat tersebut biasanya dibedakan dengan kategori semantik dan kategori tindak tutur yang dikenal sebagai pernyataan, pertanyaan, dan perintah. Kalimat deklaratif mempunyai makna proposisi, kalimat interogatif mempunyai makna pertanyaan, dan kalimat imperatif mempunyai makna perintah. Sebuah proposisi atau sebuah pertanyaan bisa memiliki daya yang ada pada suatu impositif, dan pada umumnya, dengan memakai strategi ketaklangsungan (implikatur), setiap jenis bentuk semantik dapat dipasangkan dengan berbagai jenis bentuk pragmatik (Leech, 1993: 179).

a. Kalimat Imperatif

Chaer (2016) menjelaskan bahwa kalimat imperatif merupakan kalimat yang isinya mengharapkan adanya reaksi berupa tindakan atau perbuatan dari mitra tutur. Hakikat dari makna imperatif berupa tuntutan agar seseorang memberikan reaksi atau tanggapan terhadap apa yang 


Kredo 4 (2021)
KREDO: Jurnal Ilmiah Bahasa dan Sastra
Terakreditasi Sinta 4 berdasarkan Keputusan
Direktorat Jenderal Penguatan Riset dan
Pengembangan, Kementerian Riset, Teknologi dan
Pendidikan Tinggi Republik Indonesia
Nomor: 23/E/KPT/2019.08 Agustus 2019
https://jurnal.umk.ac.id/index.php/kredo/index

dikatakannya. Rahardi (2005) mengklasifikasikan kalimat imperatif bahasa Indonesia menjadi lima, yaitu (a) kalimat imperatif biasa, (b) kalimat imperatif permintaan, (c) kalimat imperatif pemberian izin, (d) kalimat imperatif ajakan, dan (e) kalimat imperatif suruhan. Kalimat imperatif selain dapat bermakna perintah positif (suruhan), dapat pula bermakna perintah negatif (larangan).

\section{b. Kalimat Interogatif}

Kalimat interogatif adalah kalimat yang mengandung maksud menanyakan sesuatu kepada si mitra tutur (Rahardi, 2005). Chaer (2016) juga mengemukakan bahwa kalimat interogatif adalah kalimat yang mengharapkan adanya jawaban secara verbal. Berdasarkan kedua pendapat tersebut, maka kalimat interogatif intinya berupa pertanyaan. Alwi et al. (2019) menyebutkan ciri-ciri lain dari kalimat interogatif. Adapun ciri-ciri kalimat interogatif yang dimaksud adalah (1) menggunakan kata tanya, (2) diakhiri dengan tanda tanya, dan (3) pada bahasa tulis dan lisan dengan nada naik, terutama jika tidak ada kata tanya, atau suara tuturan. Rahardi (2005) membagi kalimat interogatif menjadi dua, yakni (a) kalimat interogatif total dan (b) kalimat interogatif parsial. c. Kalimat Deklaratif

Kalimat deklaratif adalah kalimat yang isinya menyampaikan pernyataan yang ditujukan kepada orang lain (Chaer 2016). Sehubungan dengan hal tersebut, Rahardi (2005) menyatakan bahwa kalimat deklaratif dalam bahasa Indonesia merupakan tuturan langsung dan tuturan tidak langsung. Ciri formal kalimat deklaratif adalah (1) pola intonasi berita, (2) apabila bersusun, inversi predikatnya di depan subjek, dan (3) tidak terdapat kata-kata tanya (apa, siapa, di mana, dan mengapa), kata-kata ajakan seperti (mari dan ayo), kata persilakan seperti (silakan atau dipersilakan), dan kata larangan (jangan). Ciri formal kalimat deklaratif menurut Keraf (1991) dalam Wahyuni (2020) terletak pada pola intonasinya yang netral dan tidak pada suatu bagian yang dapat menjadi pokok pembicaraan. Bagian tersebut ditempatkan pada bagian yang mendapatkan intonasi yang lebih keras atau penting. Dari pendapat tersebut dapat disimpulkan bahwa kalimat yang memiliki makna mengampaikan hal, mengemukakan hal atau pemberitahuan adalah pengertian dari kalimat deklaratif.

Menurut Cahyono (2016), kalimat deklaratif memiliki beberapa macam bentuk, di antaranya kalimat inversi, kalimat aktif, dan kalimat pasif. Dalam bentuk tulis kalimat deklaratif diakhiri dengan tanda titik. Sedangkan dalam bentuk lisan kalimat deklaratif berakhir dengan nada turun. 


Kredo 4 (2021)
KREDO: Jurnal Ilmiah Bahasa dan Sastra
Terakreditasi Sinta 4 berdasarkan Keputusan
Direktorat Jenderal Penguatan Riset dan
Pengembangan, Kementerian Riset, Teknologi dan
Pendidikan Tinggi Republik Indonesia
Nomor: 23/E/KPT/2019.08 Agustus 2019
https://jurnal.umk.ac.id/index.php/kredo/index

\section{Fungsi Tindak Ilokusi Bahasa Indonesia}

Berdasarkan fungsi

komunikatifnya, Searle and Searle (1969) menyederhanakan tindak ilokusi jadi lima bagian dengan deskripsi bagian yang dijabarkan menjadi fungsi deklaratif, fungsi direktif, fungsi asertif, fungsi komisif serta fungsi ekspresif. Sejalan dengan hal tersebut, Ibrahim (1993:15) dalam (Ilham, 2018) menyederhanakan tindak ilokusi menjadi empat. Penyederhanaan empat fungsi tindak ilokusi tersebut yaitu tindak asertif, komisif, direktif serta ucapan terima kasih.

\section{a. Tindak Tutur Asertif}

Menurut Searle and Searle (1969), tindakan yang menyangkut percakapan terkait kesungguhan ungkapan yang dapat dipercaya dan dinyatakan merupakan pengertian dari tindak asertif. Contohnya tindak memberikan pernyataan, tindak menyampaikan, tindak membetikan usulan, tindak membangkang, tindak mengeluh, tindak menggugat dan tindak memberitahukan.

\section{b. Tindak Tutur Direktif}

Tindak tutur direktif berungsi memengaruhi petutur atau mitra tutur agar melakukan tindakan seperti yang diungkapkan oleh si penutur. Fungsi umum atau makrofungsi direktif mencakup: menyuruh, memerintah, memohon, mengimbau, menyarankan dan tindakan-tindakan lain yang diungkapkan oleh kalimat bermodus imperatif menurut aliran formalisme. Berkaitan dengan fungsi komunikatif tersebut, Ibrahim (1993: 27) dalam (Ilham 2018) mengidentifikasi ada enam fungsi wujud verbal tindak direktif yang disesuaikan dengan fungsi komunikatifnya. Keenam fungsi wujud verbal tindak direktif adalah permohonan, pertanyaan, perintah, larangan, pemberian izin, dan penasihat.

\section{c. Tindak Tutur Komisif}

$$
\text { Searle and Searle (1969) }
$$
menyatakan bahwa tindak tutur yang bertugas untuk menerangkan penawaran atau perjanjian seperti perjanjian, pengambilan sumpah, dan tawar menawar. Selain itu, Ibrahim (1993) menyatakan, tindak komisif merupakan suatu tindak yang mewajibkan seseorang atau menolak untuk mewajibkan seseorang untuk melakukan sesuatu yang dispesifikasi dalam isi proposisinya, yang bisa juga mengspesifikasi kondisi-kondisi tempat isi itu dilakukan atau tidak harus dilakukan (Ilham, 2018).

\section{d. Tindak Tutur Ekspresif}

$$
\text { Tindak ekspresif yang }
$$
diungkapkan dalam bentuk perasaan oleh Searle (dalam Leech, 2016) diklasifikasikan atas (1) pernyataan hormat atau salam, (2) ungkapan terima 


Kredo 4 (2021)
KREDO: Jurnal Ilmiah Bahasa dan Sastra
Terakreditasi Sinta 4 berdasarkan Keputusan
Direktorat Jenderal Penguatan Riset dan
Pengembangan, Kementerian Riset, Teknologi dan
Pendidikan Tinggi Republik Indonesia
Nomor: 23/E/KPT/2019.08 Agustus 2019
https://jurnal.umk.ac.id/index.php/kredo/index

kasih, (3) permintaan maaf, (4) turut berduka cita, (5) memuji, dan (6) mengucapkan selamat.

\section{e. Tindak Tutur Deklaratif}

Tindak tutur deklaratif adalah tindak tutur yang bila performansinya berhasil akan menyebabkan korespondensi yang baik antara isi proposisional dengan realitas. Misalnya : menyerahkan diri, memecat, membebaskan, membaptis, memberi nama, mengucilkan, mengangkat, menunjuk, menentukan, menjatuhkan hukuman, memvonis, dan sebagainya Tarigan 2009: 43 dalam (Dinni Nur Solehah 2020).

\section{METODE PENELITIAN}

Penelitian ini menggunakan jenis penelitian kualitatif dengan rancangan deskriptif. Penelitian kualitatif merupakan penelitian yang dilakukan semata-mata hanya berdasarkan pada fakta yang ada atau fenomena yang memang secara empiris hidup pada penuturnya dimaksudkan sebagai jenis penelitian yang temuan-temuannya tidak diperoleh melalui prosedur statistik atau bentuk hitungan lainnya (Arikunto and Lia 2009). Pendekatan pragmatik merupakan jenis pendekatan yang digunakan di dalam penelitian ini. Tujuan pendekatan yang diterapkan dalam penelitian ini yaitu memaparkan atau menggambarkan bentuk tindak 409 | Jurnal Kredo

Vol. 4 No. 22021 tutur pendidik dalam pengajaran bahasa Indonesia di SMPN 1 Makassar.

Desain penelitian deskriptif kualitatif adalah desain penelitian yang diterapkan dalam penelitian ini. Desain penelitian ini berusaha memaparkan atau menggambarkan sasaran penelitian dengan cara yang nyata tanpa mengasingkan kejadian-kejadian dan tanpa menimbulkan perhitungan, perlakuan dan pengukuran. Yang menjadi fokus utama dalam penelitian ini yaitu tuturan ilokusi pendidik dalam pengajaran bahasa Indonesia yang berlangsung di kelas VII B, VII A, dan VIII E SMPN 1 Makassar.

Agar terhindar dari kejadian yang timbul akibat salah penafsiran variabel, maka peneliti menjelaskan pengertian dari operasional variabel yang dimaksud.

1. Tindak tutur yang memiliki fungsi untuk menyampaikan atau memberitahukan terkait suatu hal sekaligus mengerjakan suatu hal adalah pengertian dari tindak tutur ilokusi. Bentuk dari tindak tutur ilokusi yaitu Tindakan menyatakan, tawar menawar, perjanjian dan lain sebagainya.

2. Bentuk dari tindak tutur ilokusi yaitu tindakan menyatakan, tawar menawar, perjanjian dan lain sebagainya yang diwujudkan dalam bentuk kata, frasa dan kalimat. Sejalan dengan instrumen dalam penelitian ini, wujud tindakan ilokusi yang digambarkan yaitu 


Kredo 4 (2021)
KREDO: Jurnal Ilmiah Bahasa dan Sastra
Terakreditasi Sinta 4 berdasarkan Keputusan
Direktorat Jenderal Penguatan Riset dan
Pengembangan, Kementerian Riset, Teknologi dan
Pendidikan Tinggi Republik Indonesia
Nomor: 23/E/KPT/2019.08 Agustus 2019
https://jurnal.umk.ac.id/index.php/kredo/index

kalimat perintah (imperaktif), kalimat pertanyaan (interogatif) serta kalimat pernyataan (deklaratif)

a. Kalimat perintah (imperatif) merupakan kalimat yang berwujud ungkapan mendesak, memerintahkan, mengajak dan memberi permintaan yang bertujuan agar petutur mengikuti apa yang diperintahkan oleh penutur.

b. Kalimat pertanyaan (interogatif) merupakan kalimat yang bermakna memberikan pertanyaan kepada petutur. Respons yang diharapkan dalam kalimat interogatif adalah tanggapan atau jawaban yang merupakan pengakuan, penjelasan, dasar atau keterangan anggapan dari petutur.

c. Kalimat pernyataan (deklaratif) merupakan kalimat yang bermakna menyampaikan suatu hal atau pernyataan dengan tanda khusus yaitu tidak memakai pertanyaan, mengajak serta melarang.

3. Maksud dari fungsi tindak ilokusi dalam penelitian ini adalah tuturan yang dipakai oleh pendidik pada saat proses pengajaran bahasa Indonesia. Berdasarkan instrumen yang terdapat dalam penelitian ini, fungsi tindak ilokusi berupa fungsi deklaratif, direktif, komisif, asertif dan ekspresif.

a. Fungsi yang menghubungkan pembicara dengan keadaan sesungguhnya dan dapat dipercaya saat diungkapkan merupakan fungsi asertif, seperti fungsi menerangkan, fungsi menyampaikan, fungsi memberikan usulan, fungsi menentang, fungsi mengeluh, fungsi menggugat serta fungsi melaporkan.

b. Fungsi dari tindak ilokusi yang mengakibatkan beberapa respons tindakan mitra tutur merupakan bagian dari fungsi direktif, mengenai fungsi komunikasi yang menjadi dasar dalam menentukan fungsi ilokusi terbagi menjadi lima yaitu, pesan, nasihat, perintah, permohonan dan merekomendasikan.

c. Untuk mengungkapkan perjanjian atau proses tawar menawar merupakan fungsi komisif. Seperti mengucapkan janji, mengucapkan sumpah dan menawar suatu hal.

d. Fungsi yang berperan dalam menyampaikan perilaku psikologis dari orang yang berbicara terkait situasi yang tidak diutarakan secara langsung dan dapat dibuktikan kebenarannya merupakan fungsi ekspresif. Jenis fungsi ekspresif terbagi menjadi beberapa bagian seperti fungsi menyampaikan salam, fungsi menyampaikan terima kasih, fungsi permohonan maaf, fungsi turut berduka cita, fungsi memuji serta fungsi menyampaikan selamat.

e. Fungsi dari tindak ilokusi yang apabila berhasil memberikan performa maka akan membuat korespondensinya baik seperti isi antara proposisi dan kenyataan. Contohnya: menyerah, memberhentikan, melepaskan, 


Kredo 4 (2021)
KREDO: Jurnal Ilmiah Bahasa dan Sastra
Terakreditasi Sinta 4 berdasarkan Keputusan
Direktorat Jenderal Penguatan Riset dan
Pengembangan, Kementerian Riset, Teknologi dan
Pendidikan Tinggi Republik Indonesia
Nomor: 23/E/KPT/2019.08 Agustus 2019
https://jurnal.umk.ac.id/index.php/kredo/index

mempermandikan, mengasingkan, menaikkan,

mengelompokkan, menobatkan, memberikan

hukuman, serta memidana.

Bentuk data dari penelitian ini yaitu data lisan, seperti ucapan dan kalimatkalimat yang diungkapkan pendidik saat berlangsungnya pengajaran bahasa Indonesia di dalam kelas. Sumber data yang dilakukan dalam penelitian ini didapatkan dari proses wawancara secara lisan berbentuk seperangkat ucapan yang dikeluarkan oleh pendidik dalam proses pengajaran bahasa Indonesia di dalam kelas. Data penelitian didapatkan dari hasil merekam pada saat pendidik penyampaikan materi bahasa Indonesia di kelas VII B, VII A, VII E di SMPN 1 Makassar. Yang bertindak sebagai intrumen utama dalam penelitian ini yaitu peneliti sendiri yang disebut dengan peneliti sebagai instrument kunci. Tugas peneliti sebagai instrument kunci adalah melakukan pengumpulan data, melakukan analisis data, kemudian melakukan penafsiran dari data hingga menjadi laporan hasil penelitian. Pada saat mengumpulkan data, peneliti memakai gawai untuk merekam, dan membuat tabel yang digunakan untuk menganalisis data terkait bentuk dan manfaat tindak ilokusi pendidik saat proses pengajaran bahasa Indonesia di SMPN 1 Makassar. Penelitian ini menggunakan teknik pengumpulan data yang disebut dengan teknik rekam, proses rekam yang dilakukan untuk 411 | Jurnal Kredo Vol. 4 No. 22021 mendapatkan data dan dijadikan dokumen autentik. Peneliti dapat berupaya memeroleh data sebanyakbanyaknya saat proses wawancara antara peneliti dengan informan menggunakan Teknik ini. Adapun alat perekam yang digunakan berupa Adapun alat perekam yang digunakan adalah ponsel Apple dengan aplikasi recording bawaan IOS Hi-Q MP3 Voice Recorder untuk merekam suara menjadi mp3 dengan kualitas tinggi berbentuk $44 \mathrm{kHz}$.

Proses analisis data yang dilakukan dalam penelitian ini adalah analisis data medel interaktif, ini sejalan dengan model yang dikembangkan Miles dan Huberman (1992). Terdapat dua tanda khusus dalam model analisis ini, yaitu (1) model analisis dan (2) analisis selama pengumpulan data dan analisis setelah pengumpulan data. Langkah analisis data dalam model ini terbagi menjadi empat, yaitu (a) mengumpulkan data, (b) reduksi data, (c) menyajikan data, dan (d) membuat kesimpulan/verifikasi data. Penjabaran keempat langkah tersebut sebagai berikut.

1. Pengumpulan data, peneliti melakukan perekaman yang berhubungan dengan tindak ilokusi. Perekaman ini menghasilkan data kasar tentang tindak ilokusi. Data kasar ini selanjutnya diamati dan dipahami secara hermeneutik berdasarkan masalah penelitian, yakni (1) wujud tindak ilokusi bahasa Indonesia dalam pembelajaran bahasa Indonesia di 


Kredo 4 (2021)
KREDO: Jurnal Ilmiah Bahasa dan Sastra
Terakreditasi Sinta 4 berdasarkan Keputusan
Direktorat Jenderal Penguatan Riset dan
Pengembangan, Kementerian Riset, Teknologi dan
Pendidikan Tinggi Republik Indonesia
Nomor: 23/E/KPT/2019.08 Agustus 2019
https://jurnal.umk.ac.id/index.php/kredo/index

SMP Negeri 1 Makassar, (2) fungsi tindak ilokusi guru dalam pembelajaran bahasa Indonesia di SMP Negeri 1 Makassar.

2. Reduksi data, peneliti mencermati dan memahami secara hermeneutik seluruh sumber data dan data penelitian tentang tindak ilokusi, kemudian peneliti menandai dengan kode tertentu. Langkah ini menghasilkan transkrip data wacana tentang tindak ilokusi. Langkah ini merupakan proses reduksi data.

3. Penyajian data, peneliti mengidentifikasi dan mengklasifikasi seluruh data sesuai dengan butir masalah, yakni (1) wujud tindak ilokusi bahasa Indonesia dalam pembelajaran bahasa Indonesia di SMP Negeri 1 Makassar, (2) fungsi tindak ilokusi guru dalam pembelajaran bahasa Indonesia di SMP Negeri 1 Makassar.

4. Penyimpulan/ verifikasi, peneliti menafsirkan data yang teridentifikasi dan terklasifikasi dalam usaha menentukan kesatuan, kepaduan, dan hubungan antardata sehingga diperoleh makna yang utuh. Hal tersebut dimaksudkan sebagai proses sajian data dan penarikan kesimpulan.

\section{HASIL DAN PEMBAHASAN}

Berdasarkan hasil analisis data, berikut ini disajikan hasil penelitian dan pembahasannya.

\section{A. Bentuk Tindak Ilokusi Pendidik dalam Pengajaran Bahasa Indonesia}

Bentuk fungsi ilokusi pendidik pada saat pengajaran bahasa Indonesia bisa berjalan dengan memakai tuturan seperti kalimat imperaktif, interogatif, serta deklaratif.

\section{Kalimat Imperatif}

Kalimat imperatif (perintah) merupakan kalimat yang berwujud ungkapan mendesak, memerintahkan, mengajak dan memberi permintaan yang bertujuan agar petutur mengikuti apa yang diperintahkan oleh penutur. Berdasarkan hasil penelitian ditemukan bentuk fungsi ilokusi guru yang terjadi saat pengajaran bahasa Indonesia yaitu kalimat imperatif permintaan. Perhatikan data berikut;

\section{Coba Aldi, duduk depan nak...yo! \\ (Data ilokusi imperatif guru A01)}

Tuturan tersebut dikemukakan oleh guru ketika meminta seorang siswa untuk duduk di barisan bangku paling depan untuk memudahkan siswa tersebut menerima materi. Penggunaan kata 'nak' adalah bentuk penghalusan dari imperatif 'Coba Aldi, duduk di depan'

Kalimat imperatif permintaan adalah kalimat perintah yang sangat halus yang ditandai penggunaan penanda leksikal.

Selain itu, juga ditemukan kalimat imperaktif memberi izin yang termasuk 


Kredo 4 (2021)
KREDO: Jurnal Ilmiah Bahasa dan Sastra
Terakreditasi Sinta 4 berdasarkan Keputusan
Direktorat Jenderal Penguatan Riset dan
Pengembangan, Kementerian Riset, Teknologi dan
Pendidikan Tinggi Republik Indonesia
Nomor: 23/E/KPT/2019.08 Agustus 2019
https://jurnal.umk.ac.id/index.php/kredo/index

bentuk ilokusi pendidik saat pengajaran bahasa Indonesia. Kalimat imperatif pemberian izin digunakan penutur untuk mengizinkan mitra tutur melakukan suatu perbuatan atau tindakan. Berdasarkan hasil penelitian ditemukan bentuk kalimat imperatif pendidik yaitu mengajak. Kalimat imperatif ajakan bertujuan mengajak mitra tutur untuk melakukan suatu perbuatan atau tindakan. Berdasarkan hasil penelitian ini pula ditemukan wujud fungsi ilokusi guru dalam pembelajaran bahasa Indonesia berupa kalimat imperatif suruhan. Kalimat imperatif suruhan adalah kalimat yang bertujuan menyuruh mitra tutur untuk melakukan suatu perbuatan atau tindakan sesuai dengan keinginan penutur. Berdasarkan hasil penelitian ditemukan wujud fungsi ilokusi guru dalam pembelajaran bahasa Indonesia berupa kalimat imperatif larangan. Kalimat imperatif larangan bertujuan untuk melarang mitra tutur melakukan fungsi atau perbuatan yang dapat membahayakan dirinya atau orang lain.

\section{Kalimat Interogatif}

Bentuk tindak ilokusi pendidik saat pengajaran bahasa Indonesia dapat juga dilakukan dengan menggunakan tuturan berupa kalimat interogatif (pertanyaan). Kalimat pertanyaan (interogatif) merupakan kalimat yang bermakna memberikan pertanyaan kepada petutur. Respons yang diharapkan dalam kalimat interogatif adalah tanggapan atau jawaban yang merupakan pengakuan, penjelasan, dasar atau keterangan anggapan dari petutur. Terdapat dua bentuk kalimat interogatif yang ditemukan pada penelitian ini, yaitu kalimat interogatif total dan kalimat interogatif parsial. Perhatikan data berikut;

Kalimat interogatif total;

Baiklah, setelah menyimak materi yang saya jelaskan tadi, apakah anak-anak ku sekalian sudah bisa memahami? Jelas ya?

(Data ilokusi imperatif guru B01)

Kutipan tuturan guru di atas merupakan bentuk kalimat interogatif total. Sebab, guru memberikan pertanyaan kepada siswa yang hanya membutuhkan jawaban berupa 'sudah' atau 'belum' dan 'ya' atau tidak.

Kalimat interogatif parsial;

Kelompoknya Ainun coba ke depan perwakilannya! Jelaskan mengapa rekan kelompoknya mengatakan bahwa ....

(Data ilokusi imperatif guru B02)

Kutipan tuturan guru di atas merupakan bentuk kalimat interogatif parsial. Hal tersebut ditandai dengan penggunaan kata tanya 'mengapa' yang tujuannya adalah menanyakan alasan terjadinya suatu hal.

\section{3 | Jurnal Kredo}

Vol. 4 No. 22021 


Kredo 4 (2021)
KREDO: Jurnal Ilmiah Bahasa dan Sastra
Terakreditasi Sinta 4 berdasarkan Keputusan
Direktorat Jenderal Penguatan Riset dan
Pengembangan, Kementerian Riset, Teknologi dan
Pendidikan Tinggi Republik Indonesia
Nomor: 23/E/KPT/2019.08 Agustus 2019
https://jurnal.umk.ac.id/index.php/kredo/index

\section{Kalimat Deklaratif}

Berdasarkan hasil penelitian ditemukan bentuk kalimat deklaratif pasif. Perhatikan kalimat berikut;

Mel..., perhatikan dulu saya jelaskan, tadi yang kamu utarakan itu sudah dijelaskan oleh teman mu jadi tidak usah diulang lagi. Cari jawaban lain yang bisa menguatkan jawaban temanmu sebelumnya

(Data ilokusi deklaratif guru C01)

Berdasarkan tuturan di atas, dapat dijelaskan bahwa penggunaan kata 'dijelaskan' merupakan bentuk dari kalimat pasif. Sehingga dengan demikian, pernyataan dari guru mengenai keadaan penjelasan siswa dikatagorikan sebagai bentuk ilokusi deklaratif pasif.

Kalimat deklaratif aktif adalah salah satu wujud tindak ilokusi pendidik saat pengajaran Bahasa Indonesia. Kalimat deklaratif aktif adalah kalimat yang subjeknya melakukan pekerjaan atau perbuatan sesuai predikat kalimatnya. Hasil penelitian selanjutnya ditemukan bahwa kalimat deklaratif pasif adalah salah satu bentuk tindak ilokusi pendidik dalam pengajaran bahasa Indonesia. Kalimat yang memiliki subjek dikenai pekerjaan karena predikat kalimat merupakan pengertian dari kalimat deklaratif pasif.

\section{B. Fungsi Tindak Ilokusi Guru dalam Pembelajaran Bahasa Indonesia}

Berdasarkan hasil penelitian yang dilakukan, ditemukan tiga jenis fungsi tindak ilokusi pendidik saat pengajaran bahasa Indonesia, yaitu (1) fungsi asertif, (2) fungsi direktif, dan (3) fungsi ekspresif.

\section{Fungsi Asertif}

a. Menyatakan

Fungsi menyatakan ditemukan dalam hasil penelitian ini. Proses penyampaian informasi atau pikiran dari petutur kepada petutur yang mendengarkannya disebut fungsi menyatakan. Secara gramatikal tuturan yang ditemukan dalam fungsi ini berbentuk kalimat deklaratif berupa menyampaikan sesuatu. Jika diperhatikan dari segi manfaatnya, Dilihat dari fungsinya, kedua kalimat tersebut befungsi penyampaian informasi atau pikiran dari petutur kepada petutur. Dapat disimpulkan bahwa fungsi dari tuturan adalah menyampaikan atau memberitahukan suatu hal yang berlangsung dari penutur kepada petutur. Perhatikan data berikut;

Mel..., perhatikan dulu saya jelaskan, tadi yang kamu utarakan itu sudah dijelaskan oleh teman mu jadi tidak usah diulang lagi. Cari jawaban lain yang bisa menguatkan jawaban temanmu sebelumnya

(Data ilokusi fungsi asertif guru D01)

Berdasarkan tuturan pada kutipan di atas, terlihat bahwa guru memberikan 


Kredo 4 (2021)
KREDO: Jurnal Ilmiah Bahasa dan Sastra
Terakreditasi Sinta 4 berdasarkan Keputusan
Direktorat Jenderal Penguatan Riset dan
Pengembangan, Kementerian Riset, Teknologi dan
Pendidikan Tinggi Republik Indonesia
Nomor: 23/E/KPT/2019.08 Agustus 2019
https://jurnal.umk.ac.id/index.php/kredo/index

pernyataan yang sifatnya informatif kepada siswa yang bernama 'Mel'. Hal ini dikarenakan siswa tersebut salah atau melakukan pengulangan dalam memberikan informasi. Sehingga pernyataan yang diberikan guru adalah ketegasan bahwa informasi tersebut sudah diberikan oleh siswa lainnya sehingga tidak perlu diulang kembali.

\section{b. Mengusulkan}

Fungsi mengusulkan ditemukan dalam hasil penelitian ini. Salah satu hal yang disampaikan penutur kepada kepada petutur adalah fungsi mengusulkan. Dari hasil tuturan tersebut, petutur akan memberikan respon secara gramatikal, tuturan yang ditemukan dalam fungsi ini berbentuk kalimat deklaratif. Perhatikan data berikut;

Siapa tahu ada teman kelompoknya yang mau membantu Melda menjelaskan pertanyaan dari kelompok lain, Sulfikar mungkin, silahkan!.

(Data ilokusi fungsi mengusulkan D01)

Berdasarkan kutipan tuturan di atas, dapat dijelaskan bahwa guru mengusulkan kepada salah satu kelompok untuk memberikan bantuan kepada teman kelompoknya dalam menjawab pertanyaan, Guru mengusulkan Sulfikar untuk memberikan jawaban tambahan. Jika diperhatikan berdadarkan fungsinya, fungsi dari kalimat tersebut adalah mengusulkan suatu hal pada petutur. Usulan yang disampaikan penutur kemudian direspon oleh petutur.

\section{c. Membual}

Fungsi membual ditemukan dalam penelitian ini. Perhatikan data berikut;

Coba kamu jelaskan, jangan dari tadi bisanya hanya mengganggu temannya. Coba, saya mau lihat kemampuan mu!

(Data ilokusi fungsi membual D01)

Data pada kutipan tuturan tersebut menjelaskan tentang bualan guru terhadap salah satu siswa yang dinilai mengganggu jalannya proses pembelajaran. Siswa tersebut selalu mencela dan menertawai siswa lain ketika memberikan jawaban. Untuk itu, guru tidak menyenangi perbuatan tersebut sehingga guru meminta siswa tersebut untuk menampilkan kompetensinya di hadapan teman-teman guna membuktikan bahwa dia memiliki kemampuan lebih baik daripada temantemannya. Hanya saja, guru berusaha mengejek (pada poin ini yang disebut membual) siswa tersebut secara halus dengan mengatakan 'jangan dari tadi bisanya hanya mengganggu temannya'

Penyampaian suatu hal kepada petutur dengan cara terang-terangan dan menimbulkan rasa tidak percaya petutur merupakan pengertian membual. Secara 


Kredo 4 (2021)
KREDO: Jurnal Ilmiah Bahasa dan Sastra
Terakreditasi Sinta 4 berdasarkan Keputusan
Direktorat Jenderal Penguatan Riset dan
Pengembangan, Kementerian Riset, Teknologi dan
Pendidikan Tinggi Republik Indonesia
Nomor: 23/E/KPT/2019.08 Agustus 2019
https://jurnal.umk.ac.id/index.php/kredo/index

gramatikal, tuturan yang ditemukan dalam fungsi ini berupa kalimat deklaratif yang berfungsi untuk menyampaikan sesuatu, tetapi sifatnya yang bukan-bukan sehinga menimbulkan ketidakpercayaan petutur.

\section{d. Mengeluh}

Fungsi mengeluh ditemukan dalam penelitian ini. Fungsi yang diperlihatkan penutur ketika menyampaikan suatu hal kepada petutur adalah fungsi mengeluh. Penutur mengungkapkan rasa kekecewaan dengan mengeluh atas tingkah laku dan perbuatan petutur. Secara gramatikal, tuturan yang ditemukan dalam fungsi ini berbentuk kalimat deklaratif. Kalimat itu memiliki fungsi untuk memberitahukan suatu hal kepada petutur dan yang disampaikan tersebut berwujud keluhan terhadap petutur sebab adanya rasa tidak suka dengan hal yang diperbuat oleh petutur. Perhatikan data berikut;

Coba kamu jelaskan, jangan dari tadi bisanya hanya mengganggu temannya. Coba, saya mau lihat kemampuan mu!

(Data ilokusi fungsi mengeluh D01)

Data tuturan membual juga merupakan data tuturan keluhan yang disampaikan oleh guru. Keluhan yang dimaksud disini adalah keresahan yang dialami oleh guru ketika menyaksikan salah satu siswa yang tidak mengikuti proses belajar dengan bai, yaitu mencela performa belajar siswa lain. Sehingga bukti keluhan tersebut ditunjukkan dari untruksi atau perintah untuk siswa tersebut menampilkan kemampuan di hadapan teman-temannya. Hal tersebut dilakukan oleh guru untuk memberikan efek jera kepada siswa.

e. Melaporkan

Fungsi melaporkan ditemukan dalam penelitian ini. Saat penutur menyampaikan sesuatu kepada petutur dengan tujuan melaporkan suatu peristiwa dan kejadian merupakan fungsi melaporkan. Perhatikan data berikut;

Setelah nilai diskusi hari ini diakumulasi, kelompok terbaik atau pemenang hari ini adalah kelompok dua, selamat!

(Data ilokusi fungsi melaporkan E01)

Data pada kutipan di atas merupakan bentuk laporan guru yang disampaikan dihadapan siswa. Laporan tersebut menyangkut kelompok terbaik setelah dilakukan akumulasi nilai. Untuk itu, ungkapan yang disampaikan memiliki fungsi melaporkan sebuah peristiwa dan kejadian kepada petutur.

f. Menyetujui

Fungsi menyetujui ditemukan dalam penelitian ini. Perhatikan data berikut: 


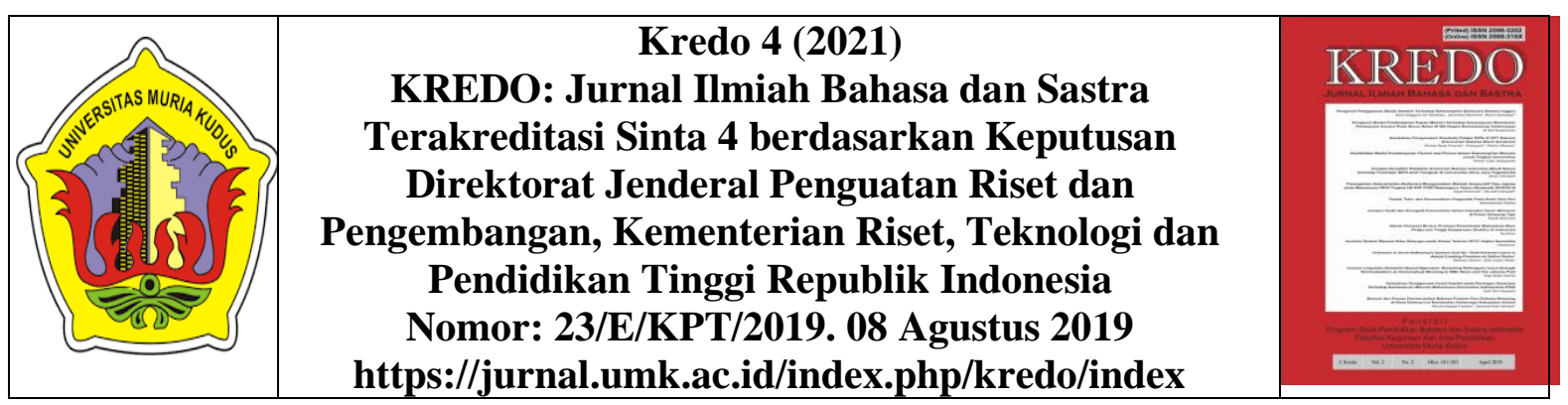

Iya boleh, silakan. Yang lain tolong di dengarkan!

(Data ilokusi fungsi menyetujui F01)

Data pada kutipan di atas dituturkan oleh guru ketika seorang siswa mengajukan diri untuk menjawab salah satu pertanyaan dari kelompok lain. Siswa meminta persetujuan dari guru karena pertanyaan tersebut tidak ditujukan untuk kelompok atau dirinya sendiri melainkan untuk kelompok lain. Untuk itu, guru memberikan persetujuan dan mempersilakan siswa memberikan jawabannya.

Penyampaian ungkapan dari penutur kepada petutur dengan tujuan supaya petutur menyetujui suatul hal yang diusulkan penutur merupakan fungsi menyetujui. Secara gramatikal, tuturan yang disampaikan dalam fungsi ini berbentuk kalimat deklaratif. Dilihat dari fungsinya, tuturan yang didapatkan seperti sebuak kalimat persetujuan suatu hal yang telah disampaikan penutur kepada petutur.

\section{g. Memprotes}

Fungus memprotes juga ditemukan dalam penelitian ini. Perhatikan data berikut;

Tunggu dulu, jangan langsung diterima saja jawabannya. Cermati dahulu apakah jawaban teman mu tadi benar atau salah. Kalau sudah benar baru boleh disetujui. Nanti kalau saya tanya alasannya kenapa setuju, apakah kelompok mu sudah paham? Begitu ya!

(Data ilokusi fungsi memprotes G01)

Data pada kutipan tuturan di atas digunakan oleh guru ketika seorang siswa dari satu kelompok memberikan pernyataan bahwa mereka telah menyetujui dan paham atas penjelasan dari kelompok lain. Namun, guru menyela komunikasi antarsiswa tersebut dan memberikan protes kepada siswa dan kelompok yang menyatakan paham dan setuju. Alasan guru melakukan protes adalah siswa belum melakukan analisis jawaban secara cermat untuk memberikan suatu keputusan.

Sebuah fungsi yang diperlihatkan penutur kepada petutur disebabkan penutur tidak menerima atau tidak sejalan dengan pernyataan yang telah disampaikan petutur. Secara gramatikal, tuturan yang ditemukan dalam fungsi ini termasuk kalimat deklaratif, dilihat dari fungsinya, dari penyampaian penutur kepada petutur berisi sebuah penolakan sebab memang penutur tidak sependapat denga hal yang dikeluarkan oleh petutur.

\section{Fungsi Direktif}

Fungsi direktif sebagai bagian dari fungsi tindak ilokusi saat peroses pengajaran bahasa Indonesia ditemukan dalam penelitian ini dan mengacu pada fungsi komunikatif. Adapun fungsi fungsi ilokusi guru dproses pengajaran 


Kredo 4 (2021)
KREDO: Jurnal Ilmiah Bahasa dan Sastra
Terakreditasi Sinta 4 berdasarkan Keputusan
Direktorat Jenderal Penguatan Riset dan
Pengembangan, Kementerian Riset, Teknologi dan
Pendidikan Tinggi Republik Indonesia
Nomor: 23/E/KPT/2019.08 Agustus 2019
https://jurnal.umk.ac.id/index.php/kredo/index

bahasa Indonesia yang ditemukan dalam penelitian ini terbagi atas enam jenis, meliputi memohon, melarang, memberikan izin, pertanyaan, memerintah, dan memberi nasihat. Paparan keenam fungsi direkti tersebut sebagai berikut. Keenam jenis fungsi direktif itu dipaparkan sebagai berikut.

\section{a. Permohonan}

$$
\text { Berdasarkan hasil penelitian }
$$
ditemukan fungsi direktif berupa permohonan. Perhatikan data berikut;

Saya harap kepada setiap siswa untuk tidak langsung setuju, paham, atau sependapat dari jawaban kelompok lain. Tetapi cermati dahulu lalu berikan alasan.

(Data ilokusi fungsi permohonan H01)

Data pada kutipan tuturan di atas adalah bentuk tuturan permohonan yang digunakan oleh guru. Bentuk permohonan tersebut tercermin dari kata 'saya harap'. Dalam penelitian ini, fungsi direktif berupa permohonan ditemukan ada dua jenis, yaitu berdoa dan memohon. Berdoa merupakan tuturan yang realisasinya berupa imperatif ajakan yang dilakukan ketika akan memulai acara. Sedangkan tuturan memohon realisasinya sama dengan imperatif suruhan. b. Larangan

Berdasarkan hasil penelitian ditemukan fungsi direktif berupa larangan. Perhatikan data berikut;

Saya harap kepada setiap siswa untuk tidak langsung setuju, paham, atau sependapat dari jawaban kelompok lain. Tetapi cermati dahulu lalu berikan alasan.

(Data ilokusi fungsi larangan I01)

Data pada kutipan di atas merupakan bentuk tuturan larangan yang digunakan oleh guru. Tuturan larangan tersebut tercermin dari tuturan 'untuk tidak langsung'. Larangan mempunyai fungsi melarang untuk melakukan sesuatu. Berkaitan dengan tuturan yang ditemukan, bahwa larangan adalah ungkapan memerintah atau menyuruh supaya petutur tidak melaksanakan suatu hal.

c. Pemberian Izin

Berdasarkan hasil penelitian ditemukan fungsi direktif berupa pemberian izin. Perhatikan data berikut;

Iya boleh, silakan. Yang lain tolong di dengarkan!

(Data ilokusi fungsi memberikan izin J01)

Data pada kutipan di atas adalah tuturan guru saat mempersilakan seorang siswa untuk menjawab. Penggunaan kata 'silakan' adalah bentuk tuturan 


Kredo 4 (2021)
KREDO: Jurnal Ilmiah Bahasa dan Sastra
Terakreditasi Sinta 4 berdasarkan Keputusan
Direktorat Jenderal Penguatan Riset dan
Pengembangan, Kementerian Riset, Teknologi dan
Pendidikan Tinggi Republik Indonesia
Nomor: 23/E/KPT/2019.08 Agustus 2019
https://jurnal.umk.ac.id/index.php/kredo/index

memberikan izin. Pemberian izin bertujuan memberikan izin kepada mitra tutur untuk melakukan apa yang diinginkan oleh penutur. Dalam penelitian ini, tuturan pemberian izin terdiri atas dua jenis, meliputi menyetujui, dan membolehkan. Tuturan pemberian izin ditandai oleh penggunaan kata boleh, silakan, dan baiklah.

\section{d. Pertanyaan}

Berdasarkan hasil penelitian ditemukan fungsi direktif berupa pertanyaan. Perhatikan data berikut;

Ada yang mau menyangga atau memberikan tambahan dari jawaban yang telah diberikan oleh kelompok satu. Kalau ada silakan angkat tangan

(Data ilokusi fungsi larangan K01)

Tuturan ini berfungsi untuk bertanya. Berkaitan dengan tuturan yang ditemukan dalam fungsi ini, bahwa pertanyaan merupakan permohonan dalam pengertian bahwa mitra tutur memberikan informasi tertentu kepada penutur Pertanyaan atau kalimat tanya adalah kalimat yang isinya mengharap respons atau tanggapan dalam wujud mengaku, memberikan keterangan, memberikan sangkalan atau perkiraan dari pihak pendengar atau pembaca. e. Perintah

Berdasarkan hasil penelitian ditemukan fungsi direktif berupa fungsi perintah. Dalam penelitian ini, fungsi perintah mempunyai dua jenis fungsi, yaitu fungsi memerintah dan fungsi mengarahkan. Perhatikan data berikut;

Coba kamu jelaskan, jangan dari tadi bisanya hanya mengganggu temannya.

(Data ilokusi fungsi perintah L01)

Berdasarkan data pada kutipan di atas menjelaskan bahwa guru memberikan perintah kepada salah seorang siswa untuk menjelaskan sebuah pertanyaan yang tidak dapat dijawab oleh siswa lain.

Berkaitan dengan tuturan fungsi perintah yang ditemukan bahwa fungsi perintah adalah ekspresi keinginan penutur supaya mitra tutur berfungsi dalam acara tertentu di mana penutur mengekspresikan maksudnya sehingga mitra tutur menyikapi keinginan yang diekspresikan oleh penutur sebagai alasan untuk bertindak.

\section{f. Menasihatkan}

Berdasarkan hasil penelitian ditemukan fungsi direktif berupa fungsi menasihatkan. Tiga fungsi menasehati ditemukan dalam penelitian ini, yakni fungsi memberikan nasihat, fungsi memberikan peringatan, dan fungsi 


Kredo 4 (2021)
KREDO: Jurnal Ilmiah Bahasa dan Sastra
Terakreditasi Sinta 4 berdasarkan Keputusan
Direktorat Jenderal Penguatan Riset dan
Pengembangan, Kementerian Riset, Teknologi dan
Pendidikan Tinggi Republik Indonesia
Nomor: 23/E/KPT/2019.08 Agustus 2019
https://jurnal.umk.ac.id/index.php/kredo/index

memberikan saran. Perhatikan data berikut:

Setelah pembelajaran hari ini, saya berharap anak-anaku sekalian mengulang materi pelajarannya di rumah. Jangan terlalu banyak main, tugas tugas sekolah mohon dikerjakan.

(Data ilokusi fungsi nasihat M01)

Berdasarkan data tuturan pada kutipan di atas, dapat dijelaskan bahwa bentuk tuturan direktif berupa nasihat guru yang diberikan kepada siswa yaitu mengulang materi setelah kembali kerumah dengan maksud agar siswa memahami dengan baik isi materi yang telah dipelajari di sekolah. Selanjutnya, guru juga memberikan nasihat untuk siswa agar tidak banyak bermain tetapi harus dibarengai dengan penyelesaian tanggung jawab mengerjakan tugas sekolah.

Berkaitan dengan tuturan yang ditemukan dalam fungsi ini, fungsi menasihatkan merupakan suatu hal yang diperlihatkan oleh penutur bukan kemauan dalam hal petutur membuat Tindakan tertentu, namun sebuah kepercayaan dalam melakukan suatu hal baik merupakan tindakan yang menunjukkan kepentingan penutur.

\section{Fungsi Ekspresif}

a. Salam

Berdasarkan hasil penelitian ditemukan fungsi ekspresif berupa fungsi salam. Fungsi ini diekspresikan sebagai wujud rasa senang bertemu atau melihat seseorang. Perhatikan data berikut;

\section{Assalamualaikum warahmatullahi wabarakatuh. Selamat siang anak- anak. Bagaimana kabarnya? \\ (Data ilokusi fungsi salam N01)}

Data pada kutipan tuturan guru di atas menjelaskan bahwa guru memberikan salam kepada siswa berupa salah dalam Islam dan salam secara umum yaitu selamat siang. Guru juga menyapa siswa dengan menanyakan kabar.

Temuan dalam fungsi ini sesuai bahwa salam merupakan ekspresi rasa senang karena telah bertemu atau melihat seseorang.

b. Berterima kasih

Berdasarkan hasil penelitian ditemukan fungsi ekspresif berupa fungsi berterima kasih. Perhatikan data berikut;

Ya... cukup bagus ya, terima kasih karena sudah membantu kelompok dua menjawab pertanyaannya.

(Data ilokusi fungsi berterima kasih O01)

Data pada kutipan di atas menjelaskan bahwa guru memberikan tuturan dengan maksud berterima kasih kepada salah seorang siswa karena telah 


Kredo 4 (2021)
KREDO: Jurnal Ilmiah Bahasa dan Sastra
Terakreditasi Sinta 4 berdasarkan Keputusan
Direktorat Jenderal Penguatan Riset dan
Pengembangan, Kementerian Riset, Teknologi dan
Pendidikan Tinggi Republik Indonesia
Nomor: 23/E/KPT/2019.08 Agustus 2019
https://jurnal.umk.ac.id/index.php/kredo/index

membantu kelompok siswa lainnya dalam menyelesaikan pertanyaan.

Berterima kasih merupakan ekspresif sebagai bentuk ucapan rasa syukur karena telah menerima atau mendapatkan sesuatu. Temuan dalam fungsi ini bahwa terima kasih merupakan ekspresi rasa syukur karena telah menerima sesuatu.

\section{c. Meminta Maaf}

Berdasarkan hasil penelitian ditemukan fungsi ekspresif berupa fungsi meminta maaf. Perhatikan data berikut;

Demikian pembelajaran kita hari ini, mohon maaf jika ada salah kata atau perbuatan. Saya akhiri pertemuan kita dengan mengucap alhamdulillah, wassalamualaikum warahmatullahi wabarakatuh.

(Data ilokusi fungsi meminta maaf P01)

Data pada kutipan tuturan diatas dituturkan oleh guru ketika hendak mengakhiri pembelajaran. Guru meminta maaf kepada siswa jika dalam proses pembelajaran sebelumnya terhadap salah perbuatan, baik sikap atau pun perkataan.

Meminta maaf merupakan ekspresi sebagai bentuk ungkapan penyesalan telah melukai atau mengganggu mitra tutur. Temuan dalam fungsi bahwa fungsi meminta maaf adalah ekspresi penyesalan karena telah melukai atau mengganggu mitra tutur.

\section{d. Pujian}

Berdasarkan hasil penelitian ditemukan fungsi ekspresif berupa fungsi pujian. Temuan ini menemukan pada saat guru mengkritik siswa, sebenarnya guru dapat membuat siswa tidak dihargai atau mengakui apa yang telah dilakukannya, namun karena penggunaan fungsi verbal pujian mengkritik yang santun dan tidak mengancam siswa, hal itu dianggap sebagai sesuatu yang baik dan patut dihargai. Perhatikan data berikut;

\section{Berkan tepuk tangan kepada kelompok empat yang sudah berhasil menjadi kelompk terbaik! \\ (Data ilokusi fungsi memuji Q01)}

Data pada kutipan di atas merupakan tuturan guru yang berbentuk ilokusi memberi pujian. Tuturan tersebut digunakan untuk memuji kinerja salah satu kelompok siswa yang telah berhasil memperoleh nilai terbaik dalam diskusi kelompok karena mampu menjawab semua pertanyaan dengan benar. Bentuk tuturan ini yang disebut tuturan pujian.

\section{SIMPULAN}

Dari paparan hasil penelitian dan pembahasan yang ada diatas, maka 


Kredo 4 (2021)
KREDO: Jurnal Ilmiah Bahasa dan Sastra
Terakreditasi Sinta 4 berdasarkan Keputusan
Direktorat Jenderal Penguatan Riset dan
Pengembangan, Kementerian Riset, Teknologi dan
Pendidikan Tinggi Republik Indonesia
Nomor: 23/E/KPT/2019.08 Agustus 2019
https://jurnal.umk.ac.id/index.php/kredo/index

dapat ditarik sebuah kesimpulan. Yang dimana kesimpulan disusun dengan berdasarkan rumusan masalah penelitian.

1. Adapun hasil pada penelitian ini mengungkapkan, bahwa bentuk tindak ilokusi pendidik di mata pelajaran Bahasa Indonesia di SMP Negeri 1 Makassar berbentuk (1) kalimat imperatif, (2) kalimat interogatif, dan (3) kalimat deklaratif. Pada penelitian ini pengunaan tindak tutur ilokusi pendidik di mata pelajaran Bahasa Indonesia yang berbentuk kalimat Imperatif terbagi menjadi lima, yaitu (1) kalimat imperatif permintaan, (2) kalimat imperatif pemberian izin, (3) kalimat imperatif ajakan, (4) kalimat imperatif suruhan, dan (5) kalimat imperatif larangan. Adapun pengunaan tindak tutur ilokusi guru dalam pembelajaran bahasa Indonesia yang berbentuk kalimat interogatif di bagi menjadi dua, yaitu (1) kalimat interogatif total, dan (2) kalimat interogatif parsial. Sedangkan pengunaan tindak tutur ilokusi guru dalam pembelajaran bahasa Indonesia yang berbentuk kalimat deklaratif yaitu (1) kalimat deklaratif aktif, dan (2) kalimat deklaratif pasif.

2. Adapun fungsi dari tindak tutur ilokusi guru pada mata pelajaran Bahasa Indonesia di SMP Negeri 1 Makassar terbagi menjadi tiga, ketiga fungsi yang dimaksudkan yaitu: (1) fungsi asertif, (2) fungsi direktif, dan

(3) fungsi ekspresif.

Pada penelitian ini fungsi asertif ditemukan ada tujuh, yaitu (1) menyatakan, (2) mengusulkan, (3) membual, (4) mengeluh, (5) melaporkan, (6) menyetujui, dan (7) memprotes. Adapun fungsi direktif yang di temukan dalam penelitian ini ada enam, yaitu (1) permohonan; fungsi pemohonan ada dua, yaitu (a) berdoa, dan (b) memohon, (2) larangan, (3) pemberian izin; fungsi pemberian izin ada dua, yakni (a) menyetujui, (b) membolehkan, (4) pertanyaan, (5) perintah; fungsi perintah ada dua, yaitu (a) memerintah, dan (b) mengarahkan, dan (6) menasihatkan; fungsi menasihatkan ada tiga, yaitu (a) menasihati, (b) memperingatkan, dan (c) menyarankan. Sedangkan fungsi ekspresif yang di temukan pada penelitian ini ada empat, yaitu (1) salam, (2) berterima kasih, (3) meminta maaf, dan (4) pujian.

\section{SARAN}

Berdasarkan dari hasil penelitian ini, maka dapat dipaparkan sebuah saran yaitu sebagai berikut:

1. Hasil penelitian ini dapat dijadikan sebagai bahan acuan dalam pembelajaran keterampilan berbahasa, khususnya keterampilan berbicara. Yang ditujukkan untuk guru bahasa dan sastra Indonesia. 


Kredo 4 (2021)
KREDO: Jurnal Ilmiah Bahasa dan Sastra
Terakreditasi Sinta 4 berdasarkan Keputusan
Direktorat Jenderal Penguatan Riset dan
Pengembangan, Kementerian Riset, Teknologi dan
Pendidikan Tinggi Republik Indonesia
Nomor: 23/E/KPT/2019.08 Agustus 2019
https://jurnal.umk.ac.id/index.php/kredo/index

2. Hasil penelitian ini dapat di jadikan sebagai bahan masukan untuk pembelajaran bahasa di sekolah dan di perguruan tinggi yang ditujukkan kepada Pemerhati pendidikan bahasa Indonesia.

3. Peneliti, disarankan untuk mengadakan penelitian terhadap wujud, fungsi, dan wujud pada ragam

\section{DAFTAR PUSTAKA}

Alwi, Hasan, Soenjono Dardjowidjojo, Hans Lapoliwa, and Anton M Moeliono. 2019. Tata Bahasa Baku Bahasa Indonesia. Jakarta: Balai Pustaka

Arikunto, Suharsimi, and Yuliana Lia. 2009. Manajemen Pendidikan. Yogyakarta: Aditya Media.

Asri. 2017. Analisis Tindak Tutur Guru dan Siswa dalam Pembelajaran Bahasa Indonesia kelas XI MAN Bulukumba. e-print.unm.

Cahyono, Bambang Eko. 2016. Kalimat Inversi Dalam Bahasa Indonesia. Indonesian Language Education and Literature 1(2): 173-93.

Chaer, Abdul. 2016. Bahasa Jurnalistik. Rineka Cipta.

Devianty, Rina. 2017. Bahasa Sebagai Cermin Kebudayaan. Jurnal tarbiyah 24(2).

Dinni Nur Solehah, Dinni. 2020. Ironi dalam Tindak Tutur Ilokusi dan Pelanggaran Prinsip Kerja Sama pada Drama Rich Man Poor Woman [リッチマン プアウーマン]のドラマにおけるアイロニの発話内行為と協調の原則の 違反 (Kajian Pragmatik).

Gorys Keraf, Dr. 2009. Diksi Dan Gaya Bahasa. Gramedia Pustaka Utama. 


Kredo 4 (2021)
KREDO: Jurnal Ilmiah Bahasa dan Sastra
Terakreditasi Sinta 4 berdasarkan Keputusan
Direktorat Jenderal Penguatan Riset dan
Pengembangan, Kementerian Riset, Teknologi dan
Pendidikan Tinggi Republik Indonesia
Nomor: 23/E/KPT/2019.08 Agustus 2019
https://jurnal.umk.ac.id/index.php/kredo/index

Ilham, Muhammad. 2018. Analisis Tindak Ilokusi Guru dalam Pembelajaran Bahasa Indonesia SMP Negeri 2 Pangkajene. In Seminar Nasional Dies Natalis UNM Ke, , 9 .

Leech, Geoffrey N. 2016. Principles of Pragmatics. London \& New York: Routledge. Purwo, Bambang Kaswanti. 1990. Pragmatik Dan Pengajaran Bahasa: Menyibak Kurikulum 1984. Kanisius.

Rahardi, R Kunjana. 2005. Pragmatik: Kesantunan Imperatif Bahasa Indonesia. Erlangga.

Searle, John R, and John Rogers Searle. 1969. 626 Speech Acts: An Essay in the Philosophy of Language. Cambridge university press.

Wahyuni, Tutik. 2020. Sintaksis Bahasa Indonesia Pendekatan Kontekstual. Penerbit Lakeisha.

Yuniarti, Netti. 2016. Implikatur Percakapan Dalam Percakapan Humor. Jurnal Pendidikan Bahasa 3(2): 225-40. 